\title{
The Effects of Triclosan on Physiological and Photosynthetic Characteristics of Chlorella vulgaris
}

\author{
Zhineng Dai ${ }^{1}{ }^{1}$, Xing Luo ${ }^{1}$, Aili Yang ${ }^{1}$, Jinsong Wang ${ }^{1}$, Haiyan Fu ${ }^{1}$ and Yicheng Wu ${ }^{1,2, *}$ \\ 1 Fujian Engineering and Research Center of Rural Sewage Treatment and Water Safety, College of \\ Environmental Science and Engineering, Xiamen University of Technology, Xiamen 361024, China; \\ daizn@xmut.edu.cn (Z.D.); haoxuexi007@163.com (X.L.); yangaililoy@xmut.edu.cn (A.Y.); \\ tuanjiefendou@163.com (J.W.); fuhy@xmut.edu.cn (H.F.) \\ 2 Hunan Provincial Key Laboratory of Water Treatment Functional Materials, Hunan University of Arts and \\ Science, Changde 415000, China \\ * Correspondence: ycwu@xmut.edu.cn
}

Citation: Dai, Z.; Luo, X.; Yang, A.; Wang, J.; Fu, H.; Wu, Y. The Effects of Triclosan on Physiological and Photosynthetic Characteristics of Chlorella vulgaris. Water 2021, 13, 1355. https://doi.org/10.3390/w13101355

Academic Editor: Antonio Zuorro

Received: 10 April 2021

Accepted: 11 May 2021

Published: 13 May 2021

Publisher's Note: MDPI stays neutral with regard to jurisdictional claims in published maps and institutional affiliations.

Copyright: (c) 2021 by the authors. Licensee MDPI, Basel, Switzerland. This article is an open access article distributed under the terms and conditions of the Creative Commons Attribution (CC BY) license (https:// creativecommons.org/licenses/by/ $4.0 /)$.
Abstract: Triclosan has been widely used as addition ingredient in personal care and medical antibacterial products, and the increasing amounts of triclosan discharged in aquatic environments pose a potential risk to aquatic ecological systems. In this study, we investigated the effects of exposure to varying triclosan concentrations on the growth, chlorophyll fluorescence and antioxidant enzyme activity of Chlorella vulgaris. The results showed that low-concentration triclosan $(<0.75 \mathrm{mg} / \mathrm{L})$ can stimulate the growth of Chlorella vulgaris, whereas $1.05 \mathrm{mg} / \mathrm{L}$ triclosan exhibited significant inhibition. Low-concentration triclosan $(<0.75 \mathrm{mg} / \mathrm{L})$ could improve the tolerance and utilization ability of Chlorella vulgaris in relation to strong light. We observed a significant increase in the malondialdehyde content of Chlorella vulgaris exposed to $1.05 \mathrm{mg} / \mathrm{L}$ triclosan. The intracellular superoxide dismutase and catalase (CAT) activities of Chlorella vulgaris exposed to triclosan were higher than the control groups, and the increase in this activity was positively correlated with the concentration of triclosan. The results also showed that excessive $\mathrm{H}_{2} \mathrm{O}_{2}$ may in turn damage the CAT structure and eventually inactivate CAT activity when Chlorella vulgaris is exposed to $1.05 \mathrm{mg} / \mathrm{L}$ triclosan. This study provided a theoretical basis which can be used to evaluate the ecological risk of triclosan in the aquatic environment.

Keywords: triclosan; Chlorella vulgaris; eco-toxicological effect; chlorophyll fluorescence

\section{Introduction}

Triclosan is a common synthetic antibacterial agent that has been used as raw material in more than 700 different industrial and pharmaceutical products [1-3]. Approximately 1220 tons of triclosan were added into personal care products in China alone in 2012 [4], and at least 350 tons of triclosan are consumed as antimicrobial agents every year in Europe [3]. It was widely detected in surface water [5-8], groundwater [9], sediment [10-12] and even in drinking water $[13,14]$ due to its extensive usage, stable chemical structure and intense antimicrobial effect [4]. Because of its hydrophobicity and lipid permeability, it is easy for triclosan to enter cells and accumulate in organisms [15]. The impact of triclosan on aquatic ecosystems has attracted worldwide attention in recent years as the remaining amount may be continuously released into the environment.

Furthermore, triclosan is linked to endocrine disruption and genetic and reproductive toxicity. Mouse poisoning test have shown that high dose triclosan exposure can lead to embryo loss. Moreover, it was also proven that exposure to triclosan may lead to contact dermatitis or skin irritation [16]. It is noteworthy that triclosan has a chronic toxic effect on aquatic organisms. The presence of triclosan in the aquatic ecosystem will affect the structure and function of seaweed organisms, and thus affect the nutrient processing ability of the ecosystem and the structure of the natural food chain. 
Microalgae, as the primary producer in the aquatic food chain, are ubiquitous in aquatic environments [17] and are often used as indicators when evaluating the quality of aquatic environments [18,19]. Algae are also often used as experimental species for assessing ecological risks and the aquatic ecotoxicology of organic pollutants [20]. In addition, chlorophyll fluorescence analysis technology provides a rapid, accurate and damage-free method of studying the photosynthetic activity of microalgae affected by pollutants [21-23]. Triclosan in industrial wastewater has been detected up to $\mathrm{mg} / \mathrm{L}$ levels [24]. High concentrations of triclosan in surface water pose great potential threats to human health and to that of aquatic ecosystems [25]. In this study, an aquatic ecological risk assessment of high-concentration triclosan was carried out by studying triclosan's effects on the growth, chlorophyll fluorescence and antioxidant enzyme activity of Chlorella vulgaris.

\section{Materials and Methods}

\subsection{Chemicals and Reagent}

Triclosan (99\% purity) was purchased from Aladdin Industrial Corporation (Shanghai, China) and the stock solution of triclosan was prepared at a concentration of $1000 \mathrm{mg} / \mathrm{L}$ in methanol (High performance liquid chromatography grade), which was purchased from Fisher Chemical (Fair Lawn, NJ, USA).

\subsection{Microalgae Culture}

The Chlorella vulgaris samples were obtained from Yuanquan Biological Technology Co., Ltd. (Haikou, China). The microalgae were cultivated in an autoclaved Erlenmeyer flask with BG11 medium (medium for blue and green algae) with a $\mathrm{pH}$ value of 7.0 [26]. Illumination was provided during microalgae cultivation using a QML4100K fluorescent light (Qiming Electronic Technology, Xiamen, China) with a $16 \mathrm{~h} / 8 \mathrm{~h}$ light/dark photoperiod and 4000 lux light intensity [27]

\subsection{Experimental Design and Test Methods}

The gradient exposure concentrations of triclosan in the test groups were $0.05,0.15$, $0.45,0.75$ and $1.05 \mathrm{mg} / \mathrm{L}$, and each group contained 3 parallel samples. The microalgae growth was analyzed on the 2nd, 4th, 8th and 10th day of exposure by means of spectrophotometry at $680 \mathrm{~nm}$, which was inter-changeable with the dry cell weight $(\mathrm{g} / \mathrm{L})$ using the equation: Dry cell weight $=0.1429 \times \mathrm{OD}_{680}, \mathrm{R}^{2}=0.9903$. The content of chlorophyll a was determined using the methanol extraction colorimetric method [28]. Malondialdehyde (MDA) and soluble protein content and superoxide dismutase (SOD) and catalase (CAT) activity were all detected using assay kits (Nanjing Jiancheng Bioengineering Institute, Nanjing, China), following the manufacturer's protocols. Chlorophyll fluorescence parameters $\left(\mathrm{Fv} / \mathrm{Fm}, \varphi\right.$ PS II, $\mathrm{I}_{\mathrm{k}}, \alpha$ and ETR $_{\max }$ ) were measured using a PHYTO-PAM phytoplankton fluorometer [29,30]. All experimental groups contained three replicates, and the data were analyzed by statistical product and service solutions (SPSS, Version 20.0) software for significance at the level of $p<0.05$ using the independent-samples $t$-test.

\section{Results and Discussion}

\subsection{Effects of Triclosan Concentration on the Growth of Chlorella vulgaris}

We detected that the triclosan concentration in water bodies surrounding a pharmaceutical production factory using triclosan as a raw material reached $0.53 \mathrm{mg} / \mathrm{L}$. In addition, our preliminary experiment showed that Chlorella vulgaris was unable to grow in BG11 medium with a triclosan concentration higher than $1.05 \mathrm{mg} / \mathrm{L}$. Figure 1 shows the effects of triclosan concentration on the growth of Chlorella vulgaris. We found that there were no growth inhibition effects on Chlorella vulgaris at any of the low-concentration treatments $(<0.75 \mathrm{mg} / \mathrm{L})$ during 4 days' exposure, compared with the control groups. Low-exposure triclosan concentrations $(<0.75 \mathrm{mg} / \mathrm{L})$ were able to significantly stimulate increases in cell density to varying degrees during 10 days' cultivation, compared with the control groups 
$(p<0.01)$, and this promotion effect was shown to be concentration-dependent. However, the growth of Chlorella vulgaris may be inhibited when exposed to $1.05 \mathrm{mg} / \mathrm{L}$ triclosan during the entire cultivation time. The dry weight of Chlorella vulgaris was $0.0620 \pm 0.0203$ $\mathrm{g} / \mathrm{L}$ on the 10 th day, which was just $23.70 \%$ of that observed in $0.75 \mathrm{mg} / \mathrm{L}$ treatments. The results showed that, in terms of growth, there were significant variations in the sensitivity of Chlorella vulgaris to different triclosan concentrations. Exposure to a low concentration $(<0.75 \mathrm{mg} / \mathrm{L})$ of triclosan was able to stimulate the growth of Chlorella vulgaris, and the degree of stimulation increased with the increase of the triclosan exposure concentration; whereas the high-exposure triclosan concentration $(1.05 \mathrm{mg} / \mathrm{L})$ significantly exhibited the inhibition of growth $(p<0.01)$. The effects of triclosan on the growth of Chlorella vulgaris showed a hormesis effect [31]. These results are consistent with the previous observation that low concentrations of ibuprofen promote the growth of the freshwater diatom Navicula sp. [32].

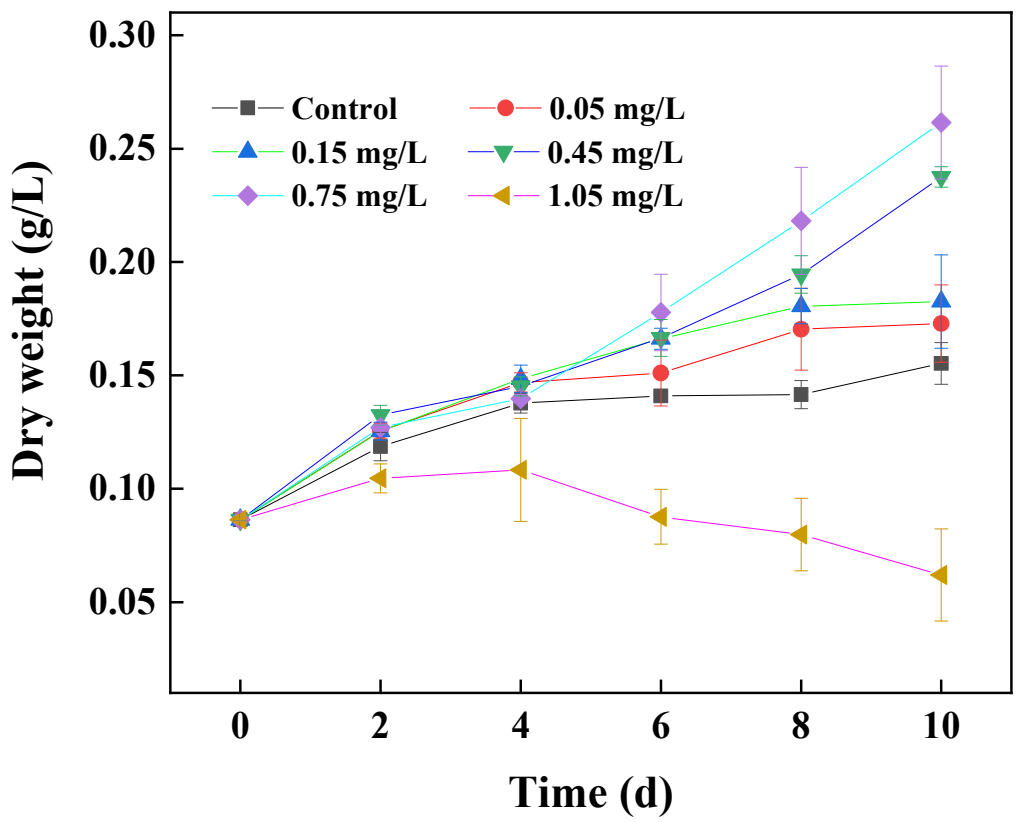

Figure 1. Effect of triclosan on the growth of Chlorella vulgaris.

\subsection{Effects of Triclosan Exposure Concentration on Chlorophyll a Content}

As an important light-collecting pigment, chlorophyll a is responsible for light energy absorption and transmission. Chlorophyll a content directly affects photosynthesis potential. The effects of triclosan concentration on chlorophyll a content in cells of Chlorella vulgaris are shown in Figure 2. As illustrated in Figure 2, low-concentration $(<0.75 \mathrm{mg} / \mathrm{L})$ triclosan had little effect on the chlorophyll content in the early stage of triclosan stress. However, as exposure time went on, there was a stable concentration-dependent stimulative effect on chlorophyll synthesis over 8 days' exposure to low-concentration $(<0.75 \mathrm{mg} / \mathrm{L})$ triclosan $(p<0.01)$. The chlorophyll a content increased to $20.18 \pm 0.64 \mathrm{mg} / \mathrm{L}$ while exposed to $0.75 \mathrm{mg} / \mathrm{L}$ triclosan, as measured on the 8 th day, which was $12.73 \pm 1.28 \mathrm{mg} / \mathrm{L}$ higher than the control groups. However, the chlorophyll a content of microalgae exposed to high-concentration triclosan (1.05 mg/L) decreased from an initial $4.44 \pm 0.05$ to $3.03 \pm$ $0.10 \mathrm{mg} / \mathrm{L}$, as measured on the 8th exposure day. These results indicate that exposure to appropriate concentrations of triclosan can promote the synthesis of chlorophyll a in microalgae cells. 


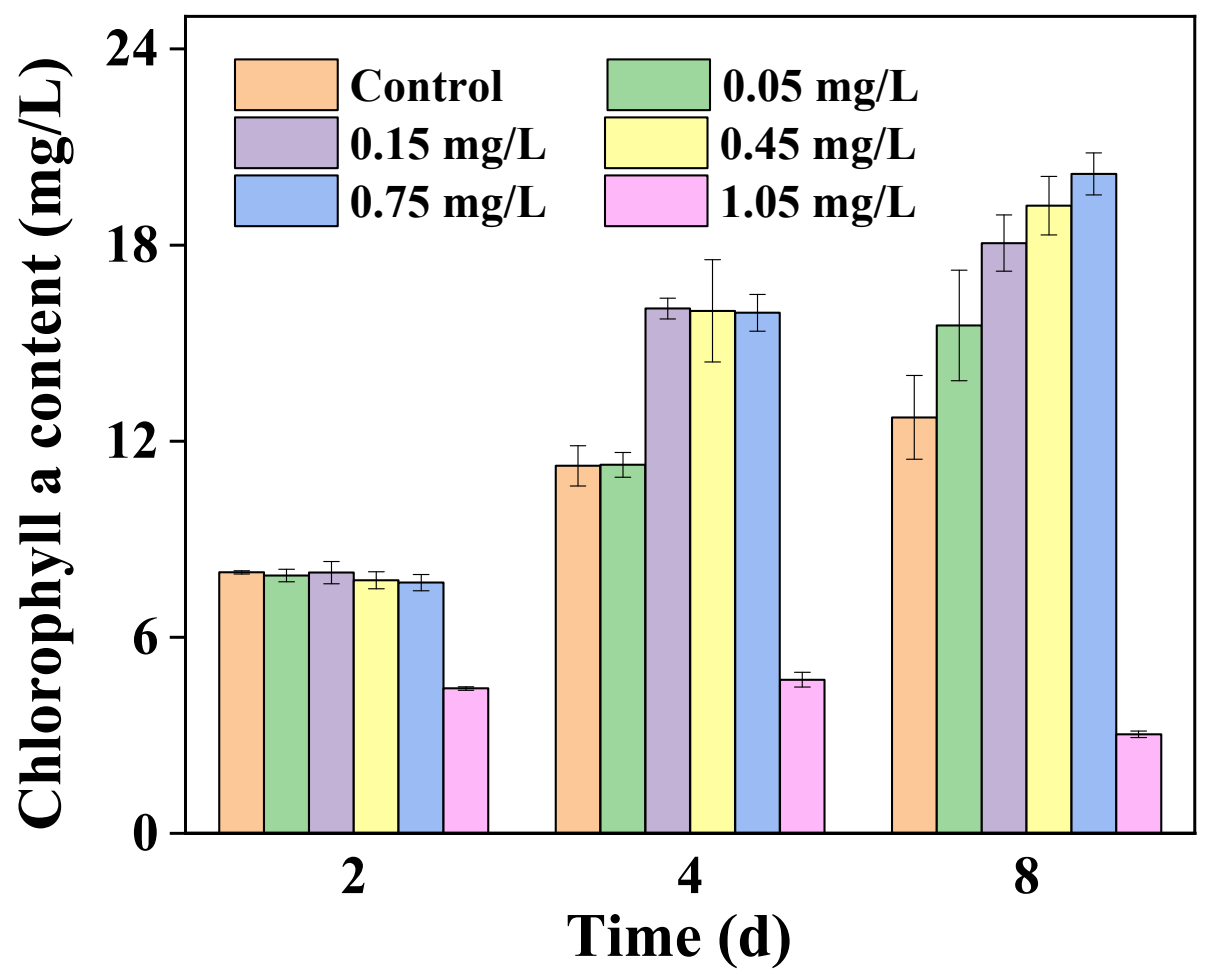

Figure 2. Effects of triclosan on the chlorophyll a content of Chlorella vulgaris.

\subsection{Effects of Triclosan on the Photochemical Efficiency of Photosystem II}

Chlorophyll fluorescence characteristics, such as actual photochemical efficiency of photosystem II (PSII) in the light ( $\varphi$ PS II), maximal photochemical efficiency of PSII $(\mathrm{Fv} / \mathrm{Fm})$, half saturated light intensity $\left(\mathrm{I}_{\mathrm{k}}\right)$, light limited slope $(\alpha)$ and photosynthetic electron transport rate (ETRmax), are often used as probes for monitoring the photochemical efficiency of PSII in microalgae cells [23]. Chlorophyll fluorescence analysis technology may provide an easy, fast and accurate way to reflect the PSII changes of microalgae under stress conditions [21].

The $\mathrm{Fv} / \mathrm{Fm}$ value is a sensitive indicator used for studying the effects of environmental factors on the potential quantum efficiency of PSII [29,33]. Figure 3 shows that the $\mathrm{Fv} / \mathrm{Fm}$ value increased slowly with the prolongation of triclosan exposure time in all low-concentration $(<0.75 \mathrm{mg} / \mathrm{L})$ treatments $(p<0.01)$. Moreover, we also found the largest $\mathrm{Fv} / \mathrm{Fm}$ value under exposure to $0.75 \mathrm{mg} / \mathrm{L}$ triclosan, whereas the smallest value was under exposure to $1.05 \mathrm{mg} / \mathrm{L}$ triclosan. This may illustrate that an excessively high concentration of triclosan had an inhibitory effect on the PSII of Chlorella vulgaris $(p<0.05)$ during the first 2 days of exposure, compared with the control groups. Moreover, we also observed that with the extension of the exposure time, $1.05 \mathrm{mg} / \mathrm{L}$ triclosan treatments exhibited no significant change in their inhibitory effect $(p>0.05)$. 


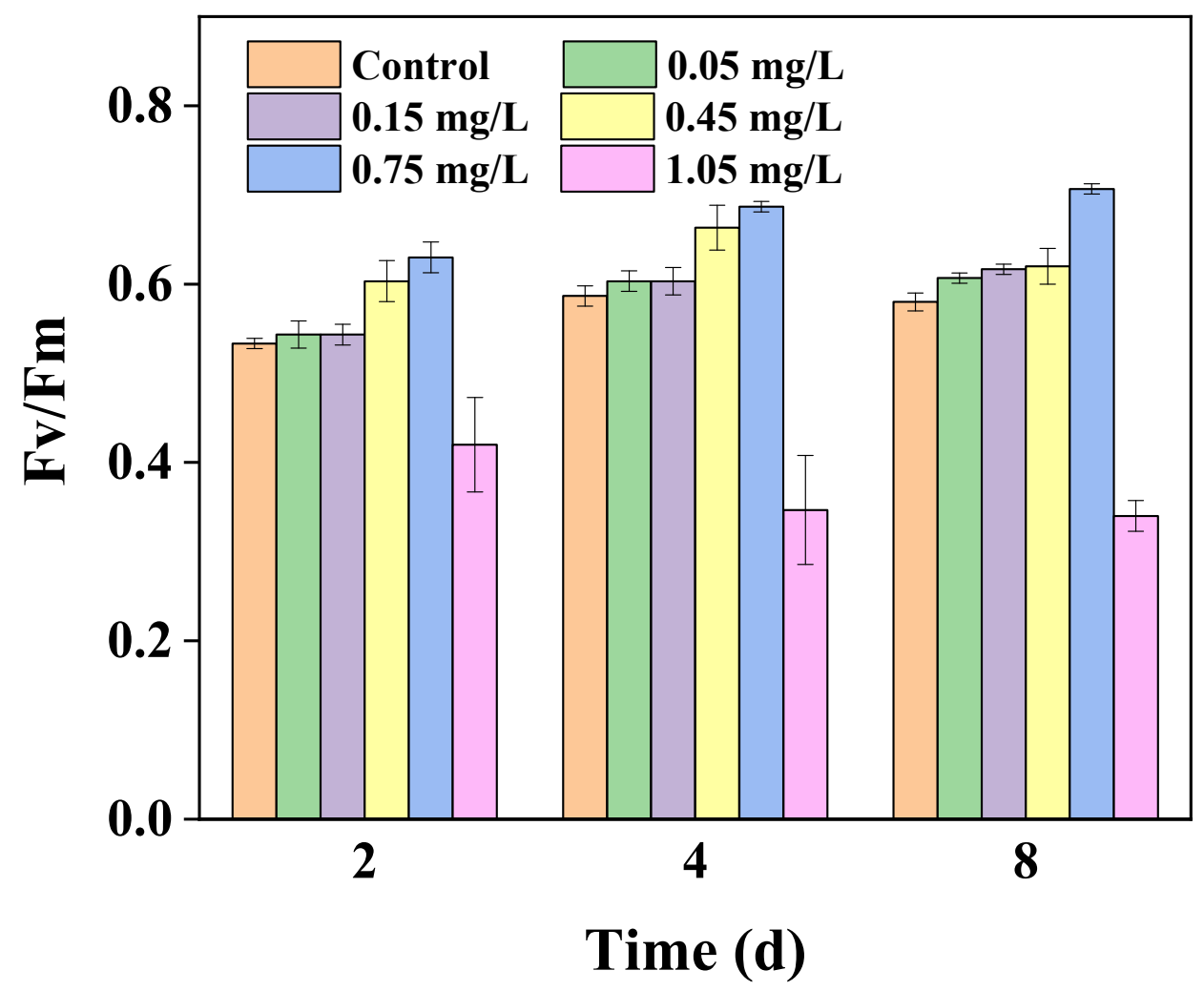

Figure 3. Effects of triclosan on the Fv/Fm value of Chlorella vulgaris.

$\varphi$ PSII reflects the actual photochemical efficiency of the PSII reaction center. Figure $4 \mathrm{a}$ shows the results of triclosan toxicity experiments with increasing triclosan exposure concentrations. It was found that $\varphi$ PSII values increased by $8.11 \%, 5.41 \%, 24.32 \%$ and $43.24 \%$, as measured on the 8th day, in samples exposed to $0.05,0.15,0.45$ and $0.75 \mathrm{mg} / \mathrm{L}$ of triclosan, respectively, as compared with the control groups. However, $\varphi$ PSII values decreased by $78 \%$ in $1.05 \mathrm{mg} / \mathrm{L}$ triclosan treatment, and the effects of triclosan on ETR $_{\max }$ were similar to its effects on $\varphi$ PSII (Figure $4 \mathrm{~b}$ ). A low concentration of triclosan was able to increase the value of $\operatorname{ETR}_{\max }(p<0.01)$, whereas the value of $\mathrm{ETR}_{\text {max }}$ decreased greatly when the concentration was increased to $1.05 \mathrm{mg} / \mathrm{L}$. Statistical analysis results indicate that the inhibitory effects of triclosan on the $\varphi$ PSII $(p<0.01)$ and ETR $\max (p<0.01)$ of Chlorella vulgaris may be highly strengthen in $1.05 \mathrm{mg} / \mathrm{L}$ treatments, compared with the control groups during the first 2 days of exposure. Moreover, with the extension of the exposure time, $1.05 \mathrm{mg} / \mathrm{L}$ triclosan treatments exhibited negligible $(p>0.05)$ changes. This may suggest that high-concentration triclosan inhibited the photosynthetic rates of Chlorella vulgaris mainly through the electron transfer chain. 

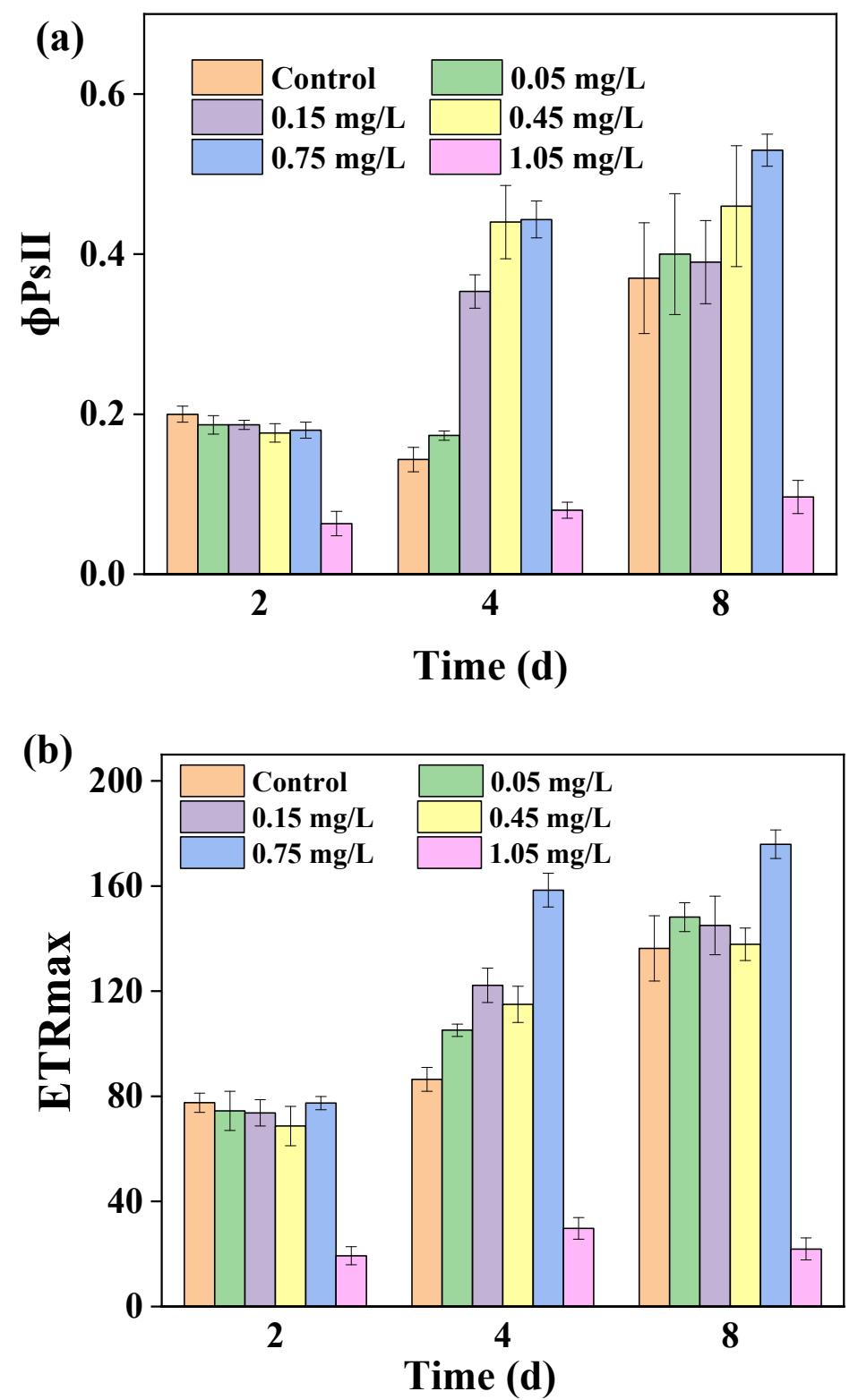

Figure 4. Effects of triclosan on the $\varphi$ PSII (a) and ETRmax (b) of Chlorella vulgaris.

The values of $I_{k}$ and $\alpha$ reflect the tolerance of microalgae to strong light and the efficiency of light energy utilization, respectively. Figure 5a showed that there was no effect exerted on the $I_{k}$ values of Chlorella vulgaris during the first two days of exposure to $0.00-0.75 \mathrm{mg} / \mathrm{L}$ triclosan. The tolerance to strong light was highly stimulated in low concentrations of triclosan $(<0.75 \mathrm{mg} / \mathrm{L})$ in algae from the 4 th exposure day $(p<0.01)$, and the extent of this increase was positively correlated with the exposure concentration. As shown in Figure $5 b$, the $\alpha$ values of Chlorella vulgaris did not change greatly along with triclosan stress at various concentrations $(0-1.05 \mathrm{mg} / \mathrm{L})$ in this study $(p>0.05)$. However, compared to the control groups, the $\alpha$ values of Chlorella vulgaris significantly decreased $(p<0.01)$ when exposed to $1.05 \mathrm{mg} / \mathrm{L}$ triclosan. Therefore, the results illustrate that lowconcentration $(<0.75 \mathrm{mg} / \mathrm{L})$ triclosan may improve the strong light tolerance and utilization ability of Chlorella vulgaris. 

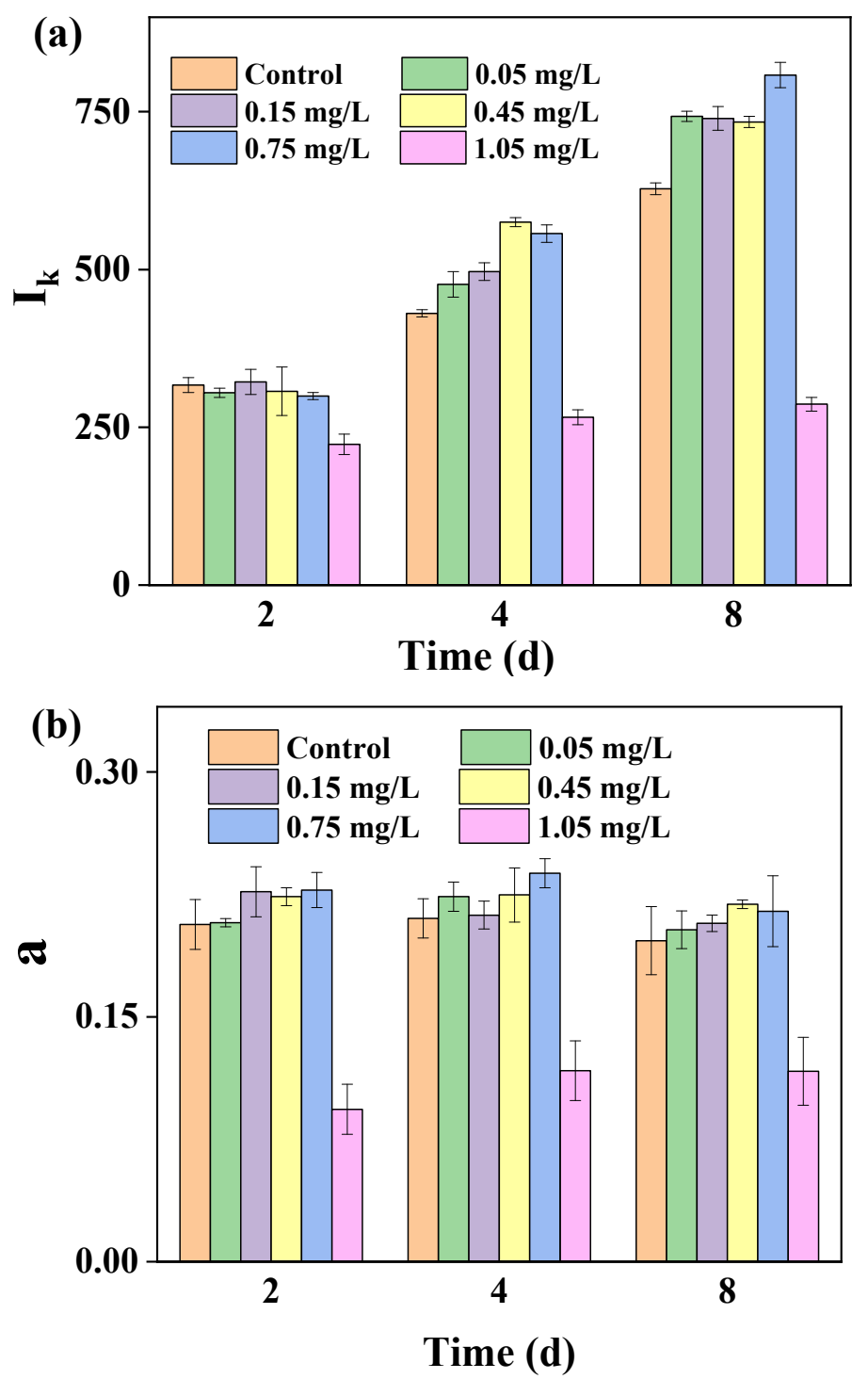

Figure 5. Effects of triclosan on the Ik (a) and $\alpha(\mathbf{b})$ values of Chlorella vulgaris.

\subsection{Effects of Exposure to Various Triclosan Concentrations on Soluble Protein Content}

Microalgae can increase osmotic pressure and the amount of enzymes by increasing the amount of intracellular soluble protein under adverse conditions in order to maintain normal metabolism [34]. Figure 6 shows the effects of different concentrations of triclosan on soluble protein content in cells of Chlorella vulgaris on the 6th day. The results illustrate that exposure to a low concentration of triclosan $(<0.75 \mathrm{mg} / \mathrm{L})$ was able to significantly increase the value of the soluble protein content in cells $(p<0.01)$, whereas this content was decreased greatly when the triclosan concentration increased to $1.05 \mathrm{mg} / \mathrm{L}$. The soluble protein content of Chlorella vulgaris slightly increased to $0.145 \pm 0.041 \mathrm{mg} / \mathrm{L}$ in $0.05 \mathrm{mg} / \mathrm{L}$ treatments, and increased to $0.427 \pm 0.018 \mathrm{mg} / \mathrm{L}$ in $0.75 \mathrm{mg} / \mathrm{L}$ treatments, which was three times higher than the control groups. However, the soluble protein content of Chlorella vulgaris decreased to $0.046 \pm 0.008 \mathrm{mg} / \mathrm{L}$ when exposed to $1.05 \mathrm{mg} / \mathrm{L}$ triclosan, a result which reached the significance level $(p<0.05)$. Moreover, the decrease in the soluble protein content was much more than that in the dry weight when the Chlorella vulgaris was exposed to $1.05 \mathrm{mg} / \mathrm{L}$ triclosan, which indicated that triclosan was not only able decrease the dry weight but also to inhibit the intracellular metabolism of microalgae. 


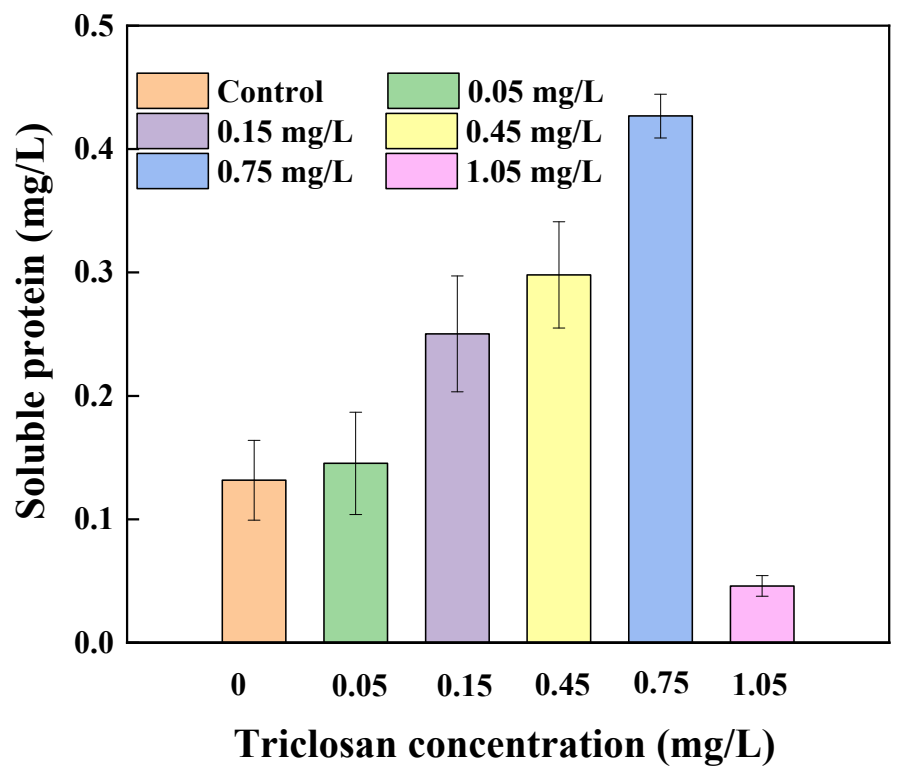

Figure 6. Effects of triclosan on the soluble protein concentration of Chlorella vulgaris.

\subsection{Effects of Triclosan on the Activity of Antioxidant Enzymes}

Triclosan removal efficiency was found to be associated with the cell density of microalgae, and the primary mechanisms of triclosan removal by microalgae were found to be photolysis, biosorption and bioaccumulation [35]. Photolysis is reported to be the primary method of triclosan removal in the natural water environment [36]. However, toxic intermediates produced by triclosan photolysis still pose a high risk to microalgae [37].

A large amount of reactive oxygen species (ROS), such as hydroxyl radical (HO), hydrogen peroxide $\left(\mathrm{H}_{2} \mathrm{O}_{2}\right)$ and superoxide $\left(\mathrm{O}_{2}{ }^{-}\right)$, are generated in the cells of microalgae under stress from organic pollutants [38]. Such over-produced ROS may accumulate in cells and oxidize the components of those cells. Thus, cellular antioxidant enzymes are synthesized in order to protect the cell structure from oxidative damage through enzymatic reactions [39].

MDA, as the final product of membrane lipid peroxidation, is usually used as an indicator of microalgae oxidative stress under stress [40]. As shown in Table 1, the MDA content of microalgae exposed to a low concentration of triclosan $(<0.75 \mathrm{mg} / \mathrm{L})$ for 6 days was slightly higher than that of the control groups. However, the MDA content in 1.05 $\mathrm{mg} / \mathrm{L}$ triclosan was nearly four times higher than that of the control groups. A significant increase in the MDA content of Chlorella vulgaris was observed under exposure to high triclosan concentrations $(p<0.01)$, which shows that the cell membrane was severely damaged by ROS.

Table 1. Effects of varying concentrations of triclosan on MDA content, CAT and SOD activities of Chlorella vulgaris.

\begin{tabular}{cccc}
\hline $\begin{array}{c}\text { Triclosan Concentration } \\
\text { (mg/L) }\end{array}$ & $\begin{array}{c}\text { MDA Content } \\
\text { (nmol/mg Protein) }\end{array}$ & $\begin{array}{c}\text { SOD Activity } \\
\text { (U/mg Protein) }\end{array}$ & $\begin{array}{c}\text { CAT Activity } \\
\text { (U/mg Protein) }\end{array}$ \\
\hline 0 & $3.935 \pm 0.405$ & $0.283 \pm 0.080$ & $6.318 \pm 0.774$ \\
0.05 & $4.116 \pm 0.363$ & $0.451 \pm 0.066$ & $7.635 \pm 0.940$ \\
0.15 & $4.028 \pm 0.710$ & $0.467 \pm 0.038$ & $9.887 \pm 1.795$ \\
0.45 & $4.111 \pm 0.340$ & $0.448 \pm 0.050$ & $12.473 \pm 1.663$ \\
0.75 & $4.234 \pm 0.301$ & $0.442 \pm 0.012$ & $13.953 \pm 0.530$ \\
1.05 & $12.865 \pm 0.424$ & $0.526 \pm 0.083$ & $9.800 \pm 0.439$ \\
\hline
\end{tabular}

SOD and CAT, as the primary antioxidant enzymes, form the first line of defense for microalgae cells to resist oxidative damage by ROS [41]. These two cellular antioxidant 
defense enzymes reduce cell damage by removing ROS. SOD is able to decompose oxygen free radicals into $\mathrm{H}_{2} \mathrm{O}_{2}$ and $\mathrm{O}_{2}$; furthermore, CAT can decompose $\mathrm{H}_{2} \mathrm{O}_{2}$ into $\mathrm{H}_{2} \mathrm{O}$ and $\mathrm{O}_{2}$, and both are very important enzymes for the metabolism of microalgae, providing defenses against oxidative damage. The CAT and SOD activities of Chlorella vulgaris exposed to different triclosan concentrations are shown in Table 1. After 6 days of exposure, SOD activity was highly stimulated, and the extent of the increase in SOD activity was highly positive correlated with the concentration of triclosan exposure $(p<0.01)$. After 6 days of exposure to $1.05 \mathrm{mg} / \mathrm{L}$ triclosan, the intracellular SOD activity was nearly two times higher than that of the control groups. It was also found that the CAT activity of Chlorella vulgaris in all low concentration treatments $(<0.75 \mathrm{mg} / \mathrm{L})$ increased during the exposure time $(p<0.01)$. The highest CAT activity in Chlorella vulgaris cells was observed in those exposed to $0.75 \mathrm{mg} / \mathrm{L}$ triclosan, which was two times higher than that of the control groups. The intracellular CAT activity and $\mathrm{H}_{2} \mathrm{O}_{2}$ concentration established a new balance in cells exposed to different concentrations of triclosan. The CAT activity was reduced from 13.953 $\pm 0.530 \mathrm{U} / \mathrm{mg}$ protein in $0.75 \mathrm{mg} / \mathrm{L}$ treatments to $9.800 \pm 0.439 \mathrm{U} / \mathrm{mg}$ protein in $1.05 \mathrm{mg} / \mathrm{L}$ treatments. This is mainly due to the fact that CAT enzymes in the cell are not capable of decomposing extremely high concentrations of $\mathrm{H}_{2} \mathrm{O}_{2}$, and excessive $\mathrm{H}_{2} \mathrm{O}_{2}$ may in turn damage the structure of CAT, and eventually may inactivate CAT enzymes [42].

\section{Conclusions}

In the present study, we identified the acute toxicity of triclosan on Chlorella vulgaris. Low-concentration $(<0.75 \mathrm{mg} / \mathrm{L})$ triclosan exposure was able to promote the growth and photosynthesis of Chlorella vulgaris, whereas chlorophyll fluorescence analysis showed that there were declines in the chlorophyll a content, photosynthetic electron transport rate and photochemical efficiency in Chlorella vulgaris exposed to high-concentration triclosan. The peroxidation of cell membrane lipids by ROS could become more severe with exposure to increasing concentrations of triclosan. Meanwhile, SOD and CAT activity were significantly promoted in order to remove ROS and reduce damage to cell structures when the Chlorella vulgaris were exposed to triclosan. CAT was sensitive to extremely high ROS, and excessive ROS inactivated CAT enzymes in cells exposed to high triclosan concentrations.

Author Contributions: Z.D. and Y.W. designed and performed the experiments; X.L. and A.Y. analyzed the data; Z.D., Y.W., H.F. and J.W. wrote the paper. All authors have read and agreed to the published version of the manuscript.

Funding: This research was funded by Natural Science Foundation of Fujian Province (2019J01848), and Scientific Climbing Plan of Xiamen University of Technology (XPDKT20016 and XPDKT20013).

Institutional Review Board Statement: Not applicable.

Informed Consent Statement: Not applicable.

Data Availability Statement: The data presented in this study are available on request from the corresponding author.

Acknowledgments: This work was supported by Natural Science Foundation of Fujian Province (2019J01848), and Scientific Climbing Plan of Xiamen University of Technology (XPDKT20016 and XPDKT20013).

Conflicts of Interest: The authors declare no conflict of interest.

\section{References}

1. Sabaliunas, D.; Webb, S.F.; Hauk, A.; Jacob, M.; Eckhoff, W.S. Environmental fate of Triclosan in the River Aire Basin, UK. Water Res. 2003, 37, 3145-3154. [CrossRef]

2. Schweizer, H.P. Triclosan: A widely used biocide and its link to antibiotics. FEMS Microbiol. Lett. 2001, 202, 1-7. [CrossRef] [PubMed]

3. Singer, H.; Müller, S.; Tixier, C.; Pillonel, L. Triclosan: Occurrence and fate of a widely used biocide in the aquatic environment: Field Measurements in wastewater treatment plants, surface waters, and lake sediments. Environ. Sci. Technol. 2002, 36, 4998-5004. [CrossRef] [PubMed] 
4. Wang, L.; Liu, Y.; Wang, C.; Zhao, X.; Mahadeva, G.D.; Wu, Y.; Ma, J.; Zhao, F. Anoxic biodegradation of triclosan and the removal of its antimicrobial effect in microbial fuel cells. J. Hazard. Mater. 2018, 344, 669-678. [CrossRef]

5. Kookana, R.S.; Ying, G.-G.; Waller, N.J. Triclosan: Its occurrence, fate and effects in the Australian environment. Water Sci. Technol. 2011, 63, 598-604. [CrossRef]

6. Villaverde-de-Sáa, E.; González-Mariño, I.; Quintana, J.B.; Rodil, R.; Rodríguez, I.; Cela, R. In-sample acetylation-non-porous membrane-assisted liquid-liquid extraction for the determination of parabens and triclosan in water samples. Anal. Bioanal. Chem. 2010, 397, 2559-2568. [CrossRef]

7. Robert, L.; Jan, W.; Tania, H.; Georg, H. Polar herbicides, pharmaceutical products, perfluorooctanesulfonate (PFOS), perfluorooctanoate (PFOA), and nonylphenol and its carboxylates and ethoxylates in surface and tap waters around lake maggiore in northern Italy. Anal. Bioanal. Chem. 2007, 387, 1469-1478.

8. Kantiani, L.; Farré, M.; Asperger, D.; Rubio, F.; González, S.; López-de-Alda, M.J. Triclosan and methyl-triclosan monitoring study in the northeast of Spain using a magnetic particle enzyme immunoassay and confirmatory analysis by gas chromatography-mass spectrometry. J. Hydrol. 2008, 361, 1-9. [CrossRef]

9. Sorensen, J.; Lapworth, D.; Nkhuwa, D.; Stuart, M.; Gooddy, D.; Bell, R.; Chirwa, M.; Kabika, J.; Liemisa, M.; Chibesa, M.; et al. Emerging contaminants in urban groundwater sources in Africa. Water Res. 2015, 72, 51-63. [CrossRef]

10. Zhao, J.-L.; Ying, G.-G.; Liu, Y.-S.; Chen, F.; Yang, J.-F.; Wang, L. Occurrence and risks of triclosan and triclocarban in the Pearl River system, South China: From source to the receiving environment. J. Hazard. Mater. 2010, 179, 215-222. [CrossRef]

11. Agüera, A.; Fernández-Alba, A.R.; Piedra, L.; Piedra, L.; Mézcua, M.; Gómez, M.J. Evaluation of triclosan and biphenylol in marine sediments and urban wastewaters by pressurized liquid extraction and solid phase extraction followed by gas chromatography mass spectrometry and liquid chromatography mass spectrometry. Anal. Chim. Acta 2003, 480, 193-205. [CrossRef]

12. Wilson, B.; Zhu, J.; Cantwell, M.; Olsen, C.R. Short-term dynamics and retention of Triclosan in the lower Hudson River Estuary. Mar. Pollut. Bull. 2008, 56, 1230-1233. [CrossRef] [PubMed]

13. Li, X.; Ying, G.-G.; Su, H.-C.; Yang, X.-B.; Wang, L. Simultaneous determination and assessment of 4-nonylphenol, bisphenol A and triclosan in tap water, bottled water and baby bottles. Environ. Int. 2010, 36, 557-562. [CrossRef] [PubMed]

14. Benotti, M.J.; Trenholm, R.A.; Vanderford, B.J.; Holad, J.C.; Stanford, B.D.; Snyder, S.A. Pharmaceuticals and endocrine disrupting compounds in U.S. drinking wate. Environ. Sci. Technol. 2009, 43, 597-603. [CrossRef] [PubMed]

15. Quan, B.; Li, X.; Zhang, H.; Zhang, C.; Ming, Y.; Huang, Y.; Xi, Y.; Weihua, X.; Yunguo, L.; Tang, Y. Technology and principle of removing triclosan from aqueous media: A review. Chem. Eng. J. 2019, 378, 122185. [CrossRef]

16. Bedoux, G.; Roig, B.; Thomas, O.; Dupont, V.; Le Bot, B. Occurrence and toxicity of antimicrobial triclosan and by-products in the environment. Environ. Sci. Pollut. Res. 2012, 19, 1044-1065. [CrossRef] [PubMed]

17. Coogan, M.A.; Edziyie, R.E.; Point, T.W.L.; Venables, B.J. Algal bioaccumulation of triclocarban, triclosan, and methyl-triclosan in a North Texas wastewater treatment plant receiving stream. Chemosphere 2007, 67, 1911-1918. [CrossRef]

18. Jiang, Y.-J.; He, W.; Liu, W.-X.; Qin, N.; Ouyang, H.-L.; Wang, Q.-M.; Kong, X.-Z.; He, Q.-S.; Yang, C.; Yang, B.; et al. The seasonal and spatial variations of phytoplankton community and their correlation with environmental factors in a large eutrophic Chinese lake (Lake Chaohu). Ecol. Indic. 2014, 40, 58-67. [CrossRef]

19. Ouyang, H.L.; Kong, X.Z.; Lavoie, M.; He, W.; Qin, N.; He, Q.S.; Yang, B.; Wang, R.; Xu, F.L. Photosynthetic and cellular toxicity of cadmium in Chlorella vulgaris. Environ. Toxicol. Chem. 2013, 32, 2762-2770. [CrossRef] [PubMed]

20. Jiao, Y.; Ouyang, H.-L.; Jiang, Y.-J.; Kong, X.-Z.; He, W.; Liu, W.-X.; Yang, B.; Xu, F.-L. Effects of phosphorus stress on the photosynthetic and physiological characteristics of Chlorella vulgaris based on chlorophyll fluorescence and flow cytometric analysis. Ecol. Indic. 2017, 78, 131-141. [CrossRef]

21. Govindje, E. Sixty-Three Years Since Kautsky: Chlorophyll a Fluorescence. Funct. Plant Biol. 1995, 22, 131-160. [CrossRef]

22. Krause, G.H. Photoinhibition of photosynthesis. An evaluation of damaging and protective mechanisms. Physiol. Plant. 1988, 74, 566-574. [CrossRef]

23. Lazar, D. Chlorophyll a fluorescence induction. Biochim. Biophys. Acta (BBA) Bioenerg. 1999, 1412, 1-28.

24. Davis, E.F.; Klosterhaus, S.L.; Stapleton, H.M. Measurement of flame retardants and triclosan in municipal sewage sludge and biosolids. Environ. Int. 2012, 40, 1-7. [CrossRef] [PubMed]

25. Poole, A.C.; Pischel, L.; Ley, C.; Suh, G.; Goodrich, J.K.; Haggerty, T.D.; Ley, R.E.; Parsonnet, J. Crossover Control Study of the Effect of Personal Care Products Containing Triclosan on the Microbiome. mSphere 2016, 1, 1-15. [CrossRef]

26. Yoon, J.H.; Sang, J.S.; Kim, M.S.; Tai, H.P. High cell density culture of Anabaena variabilis using repeated injections of carbon dioxide for the production of hydrogen. Int. J. Hydrogen Energy 2002, 27, 1265-1270. [CrossRef]

27. Li, Y.; Zhou, W.; Hu, B.; Min, M.; Chen, P.; Ruan, R.R. Integration of algae cultivation as biodiesel production feedstock with municipal wastewater treatment: Strains screening and significance evaluation of environmental factors. Bioresour. Technol. 2011, 102, 10861-10867. [CrossRef]

28. Xiong, J.Q.; Kurade, M.B.; Abou-Shanab, R.A.I.; Ji, M.K.; Choi, J.; Kim, J.O.; Jeon, B.H. Biodegradation of carbamazepine using freshwater microalgae chlamydomonas mexicana and scenedesmus obliquus and the determination of its metabolic fate. Bioresour. Technol. 2016, 205, 183-190. [CrossRef]

29. Henriques, F.S. Leaf Chlorophyll Fluorescence: Background and Fundamentals for Plant Biologists. Bot. Rev. 2009, 75, 249-270. [CrossRef] 
30. Campbell, D.; Hurry, V.; Clarke, A.K.; Gustafsson, P.; Oquist, G. Chlorophyll fluorescence analysis of cyanobacterial photosynthesis and acclimation. Microbiol. Mol. Biol. Rev. 1998, 62, 667-683. [CrossRef]

31. Wang, N.; Li, H.; Wang, L.; Zhang, L.; Xu, Y. Effects of chitosan-RE3+-bentonite on growth of Chlorella vulgaris. J. Rare Earths 2010, 28, 149-153. [CrossRef]

32. Ding, T.; Yang, M.; Zhang, J.; Yang, B.; Lin, K.; Li, J.; Gan, J. Toxicity, degradation and metabolic fate of ibuprofen on freshwater diatom Navicula sp. J. Hazard. Mater. 2017, 330, 127-134. [CrossRef]

33. Maxwell, K.; Johnson, G.N. Chlorophyll fluorescence-A practical guide. J. Exp. Bot. 2000, 51, 659-668. [CrossRef] [PubMed]

34. Singh, V.; Pandey, B.; Suthar, S. Phytotoxicity and degradation of antibiotic ofloxacin in duckweed (Spirodela polyrhiza) system. Ecotoxicol. Environ. Saf. 2019, 179, 88-95. [CrossRef]

35. Bai, X.; Acharya, K. Removal of seven endocrine disrupting chemicals (EDCs) from municipal wastewater effluents by a freshwater green alga. Environ. Pollut. 2019, 247, 534-540. [CrossRef] [PubMed]

36. Wu, J.L.; Ji, F.; Zhang, H.; Hu, C.; Wong, M.H.; Hu, D.; Cai, Z. Formation of dioxins from triclosan with active chlorine: A potential risk assessment. J. Hazard. Mater. 2019, 367, 128-136. [CrossRef] [PubMed]

37. Roberts, J.; Price, O.R.; Bettles, N.; Rendal, C.; Van Egmond, R. Accounting for dissociation and photolysis: A review of the algal toxicity of triclosan. Environ. Toxicol. Chem. 2014, 33, 2551-2559. [CrossRef]

38. Piddington, D.L.; Fang, F.C.; Laessig, T.; Cooper, A.M.; Orme, I.M.; Buchmeier, N.A. Cu, Zn Superoxide Dismutase of Mycobacterium tuberculosis Contributes to Survival in Activated Macrophages That Are Generating an Oxidative Burst. Infect. Immun. 2001, 69, 4980-4987. [CrossRef]

39. Winston, G.W.; Gioliu, R.T.D. Prooxidant and antioxidant mechanisms in aquatic organisms. Aquat. Toxicol. 1991, 19, 137-161. [CrossRef]

40. Lu, Y.; Jin, H.; Shao, B.; Xu, H.; Xu, X. Physiological and biochemical effects of triclocarban stress on freshwater algae. SN Appl. Sci. 2019, 1, 1685. [CrossRef]

41. Rocha, S.; Gomes, D.; Lima, M.; Da Rocha, E.B.; Santos-Silva, A. Peroxiredoxin 2, glutathione peroxidase, and catalase in the cytosol and membrane of erythrocytes under $\mathrm{H}_{2} \mathrm{O}_{2}$-induced oxidative stress. Free Radic. Res. 2015, 49, 990-1003. [CrossRef] [PubMed]

42. Sun, H.; Lü, K.; Minter, E.J.; Chen, Y.; Yang, Z.; Montagnes, D.J. Combined effects of ammonia and microcystin on survival, growth, antioxidant responses, and lipid peroxidation of bighead carp Hypophthalmythys nobilis larvae. J. Hazard. Mater. 2012, 221-222, 213-219. [CrossRef] [PubMed] 